\title{
Technological Competences: A Systematic Review of the Literature in 22 Years of Study
}

\author{
https://doi.org/10.3991/ijet.v14i04.9118 \\ Norma Candolfi Arballo( $\left.{ }^{\varpi}\right)$ \\ Autonomous University of Baja California, México \\ ncandolfi@uabc.edu.mx \\ María Elena Chan Núñez \\ University of Guadalajara, Jalisco, México \\ Bernabé Rodríguez Tapia \\ Autonomous University of Baja California, México
}

\begin{abstract}
In this Systematic Review of the Literature (SRL) the term "technological competence" is analyzed. The analysis is conducted within the areas of knowledge in which the term has been studied, considering the definitions that have been associated to the term, the approaches proposed by the authors that make use of the term, the transformation of the concept throughout the time, and the boundaries of application with other similar terms, such as technological capability and technological skill. A total of 140 publications focused on technological competences are analyzed. The publications correspond to a time span ranging from 1994 to 2016, and include research articles from recognized databases and, to a lesser extent, gray literature articles. Finally, the term technological competence applied in the productive sector is redefined such as it allows focusing on projects for technological absorption or training in industry.
\end{abstract}

Keywords-Technological competences, e-competences, technological capability, e-skills.

\section{Introduction}

The term technological competence represents the central focus of the SRL, which is intended to define a particular concept applied to the productive/industrial sector.

A first discussion related to the term technological competence in industry within the context of the Information, Communication and Collaboration Technologies (ICCT), is about the specialization in knowledge management. Technological competences can be understood as specific performance applied to different professional fields. From this perspective, two types of competences are required when it comes to professional performance: technological competences and professional field's specific competences. Therefore, when a professional task that requires a technological com- 
petence is performed, actually both types of competences are being used, each with its own operational logic.

Secondly, technological competences are articulated with specific knowledge of the different professional fields. Hence, the technological competences would act transversally for processing information, knowledge, communication and intelligence in any professional field. Related to the performance, it is expected that the technological competence operates symbiotically with other field-specific competences, this is, one competence type cannot be separated from another. In this sense, technological competences would appear as a "modelers" of the professional competences.

The conceptualization of technological competence and the identification of its significant features for designing suitable training and evaluation proposals for enterprises (companies) are obtained by analyzing and comparing all the definitions associated with it, from multiple approaches in the professional field, along with its transformation throughout the time.

The present study is divided into six sections. The first section is devoted to justify the SRL and the objectives and research questions are pointed out. The second section addresses the SRL method by describing the search parameters, discrimination process, coding and every aspect related to the identification and classification of the information. In the third section, the graphical results of the SRL are provided and briefly analyzed in order to point out the main findings. The fourth section presents the discussion of the findings as well as the conclusions, where the research questions are clearly resolved. Fifth and sixth sections correspond to references and authors information, respectively.

\subsection{Objective of the review}

To analyze the concept of technological competence and its relationship with capability and technological skill as conceived from the seminal origin of the term, the transformation of its meaning throughout the time, the field of knowledge of its creation, conceptualization and correlation among the terms related, and the re-definition of the technological competence applied to the industrial sector.

\subsection{Research questions}

This investigation is focused on a deep understanding of the technological competence concept. Furthermore, it is intended to provide insightful responses to the following research questions:

- Which are the elements that best describe the characteristics of a technological competence?

- What are the approaches and their conceptual relationship associated to the technological competence term?

- How the concept of technological competence has changed throughout the time?

- Which terms are relevant to the concept of technological competence? 


\section{Review Method}

The SRL is presented from a theoretical-conceptual perspective about the term technological competence with the respect to an epistemic construction.

The analysis is based on the review of research works that have been published between 1994 and 2016, considering the exploration of the term technological competence and the difference between capability and technological skill. The analyzed papers are classified into three approaches: enterprise, educational and economical. Throughout this paper, the term "data" is regarded to the results obtained from the SRL.

\subsection{Reference framework for information search}

The first step towards the integration of the SRL was to establish the conditions necessary for collecting the data that would guide the search of published papers. An important aspect was to consider only research works focused on the conceptualization of the term from a theoretical perspective.

The search was conducted in the databases of the Association for Computing Machinery (ACM), EBSCO Host, ELSEVIER, Institute of Electrical and Electronics Engineers (IEEE), JSTOR, SCOPUS and ScienceDirect.

Also, gray literature was considered as long as it belongs to international organizations, government institutions and doctoral dissertations. It is worth mentioning that grey literature is mostly obtained from citations included in the primary sources of information analyzed.

\subsection{Search criteria}

The search was conducted using the terms competence, capability and skill, considering a theoretical-conceptual perspective, intersected with the word technology. Boolean operators were used for applying these search criteria.

The keywords considered during the search are: ecompetence, technology competence, technological competencies, technological competence, ICT competence, digital competence, computing competence, technology capability, technology skill, eskills, IT-Skills.

The specific search criteria executed in the search engine of each database is: "ecompetence" OR "technology* competence" OR "technological competence" OR "ICT Competence" OR "digital competence* OR "computing* competence*” OR "technology* capability” OR "technology skill**” OR "e-skills" OR "IR-Skills**”.

Once the search was conducted, the obtained data is sorted by relevance to the subject of study, in order to clearly identify which is the most convenient contribution of each work. 


\subsection{Screening of the literature}

Screening of the literature consists in determining whether or not the papers comply with the following features and conditions:

- The paper provides a theoretical study or it contains a comprehensive empirical framework.

- The publication year is not constrained, since it is of interest to investigate how term technological competence has evolved over the years.

- Studies carried out within any area of knowledge can be considered.

- Studies published in English are preferred. However, works published in Spanish can be considered as long as they belong to publishers of recognized quality.

- Gray literature can be admitted given that it provides the perspective of international organisms about the technological competences. Also doctoral dissertations can be included provided that they are from recognized educational institutions.

- Papers must strictly consider the terms competence, capability or technological skill from a development of human potential point of view.

- The terms competence, capability and skill must be strictly referred to the technology ambit, papers that address these terms unrelated to technology would not be considered.

Preliminary results of the search, prior to screening and selection process, provided a total of 50,756 published works. Table 1 presents the number of papers corresponding to each of the considered databases.

Table 1. Number of publications per database

\begin{tabular}{|l|c|}
\hline \multicolumn{1}{|c|}{ Database } & Number of publications \\
\hline Association for computing machinery (ACM) & 38707 \\
\hline EBSCO Host & 729 \\
\hline ELSEVIER & 5045 \\
\hline Institute of Electrical and Electronics Engineers (IEEE) & 1285 \\
\hline JSTOR & 1617 \\
\hline SCOPUS & 2571 \\
\hline Science Direct & 802 \\
\hline
\end{tabular}

After the screening process, 140 papers were selected for the analysis. Selected papers are classified as articles for dissemination of science and gray literature, being $67 \%$ of the former and $33 \%$ of the latter. There is a significant different among the number of papers pre-selected during the search process and the number of selected papers after the screening process. However, this is something expected due to the application of the selection criteria, where the description and definition of the technological competence is considered only from a theoretical-conceptual perspective.

During the screening process, it was observed that the conditions with the highest exclusion ratio are: a) Papers must strictly consider the terms competence, capability or technological skill from a development of human potential point of view, and b) The terms competence, capability and skill must be strictly referred to the technology 
ambit, papers that address these terms unrelated to technology would not be considered.

\subsection{Codification and data selection}

After the screening process, a codification system was established to classify the collected data according to specific terms. A total of five indexing terms were considered, defined as: technological learning, technological capability, technological skill, core/basic competence and technological competence. The latter is further classified into three categories according to the geographical region of the publisher, given the previously importance of this matter. Table 2 presents the classification of collected data by indexing terms.

Table 2. Classification of data by definition of terms

\begin{tabular}{|c|c|c|c|c|c|}
\hline \multicolumn{2}{|c|}{ Classification by definition of terms } & Scientific articles & $\begin{array}{c}\text { Gray } \\
\text { literature }\end{array}$ & $\begin{array}{c}\text { Total } \\
\text { publications }\end{array}$ & $\%$ by term \\
\hline \multicolumn{2}{|c|}{ Technological learning } & 11 & 1 & 12 & $8.6 \%$ \\
\hline \multicolumn{2}{|c|}{ Technological capability } & 17 & 0 & 17 & $12.1 \%$ \\
\hline \multicolumn{2}{|c|}{ Technological skill } & 7 & 9 & 16 & $11.4 \%$ \\
\hline \multicolumn{2}{|c|}{ Core/Basic competence } & 15 & 0 & 15 & $10.7 \%$ \\
\hline \multirow{3}{*}{$\begin{array}{l}\text { Technological } \\
\text { competence }\end{array}$} & Regional & 2 & 1 & 3 & $2.1 \%$ \\
\hline & National & 5 & 8 & 13 & $9.3 \%$ \\
\hline & International & 36 & 28 & 64 & $45.7 \%$ \\
\hline
\end{tabular}

The definitions associated with the terms technological competence, technologic capability and technological skill were thoroughly analyzed in each paper, in order to determine how the concept was specifically applied and how it was related to other authors. This allows classifying each research work into one of the dimensions proposed in table 2 .

Given that the technological competence is the focus of this research work, the 80 papers that fall into the technological competence dimension, which represent $57.1 \%$ out of the overall selected research works, have the most impact to re-define the concept of technological competence associated to the industry. Nevertheless, the rest of the research works that fall into the other dimensions constitute a reference framework and outline for the concept.

It was identified during the screening process that the terms technological capability and technological skill are intersected with the term technological competence. Therefore, as part of the results, the relationship and main differences between: a) technological competence and technological capability, and b) technological competence and technological skill, are concisely described.

With respect to the term technological learning, from the analysis of the studies provided by [1][2][3][4][5][6][7][8][9][10] we identified that it could be associated to the lifelong education in matter of technology. Hence, it has no similarities, from a conceptual perspective, with the technological competence. On the other hand, based on the studies carried out in [11][12][13][14][15][16][17], the term core/basic competence corresponds to a more general concept related to technical, administrative and 
professional knowledge, that is not limited to the technological aspects, in consequence there is no need to compare it to the technological competence term.

\section{Results of the Review}

The results obtained from the SRL are divided into two dimensions:

- Individually: Conceptual analysis of the technological competence, how the concept has been transformed throughout the time and how other authors relate the concept, nomenclature and application approaches

- Collectively: conceptual comparatives of the technological competence with respect to technological capability and technological skill terms. The general structure of the achieved results is depicted in Figure 1.

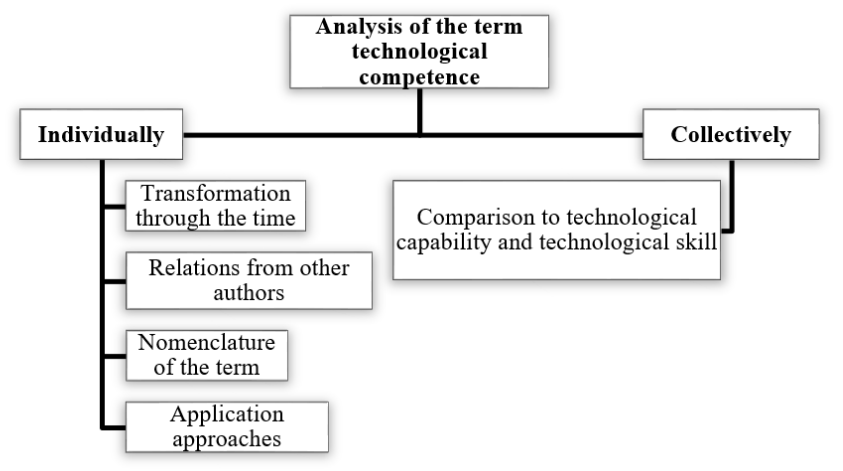

Fig. 1. General structure of achieved results

Collected data are referred to research works conducted by universities, research and development centers, public and private organizations, located in several countries. Figure 2 provides the representativeness of each publication country as observed in the selected data.

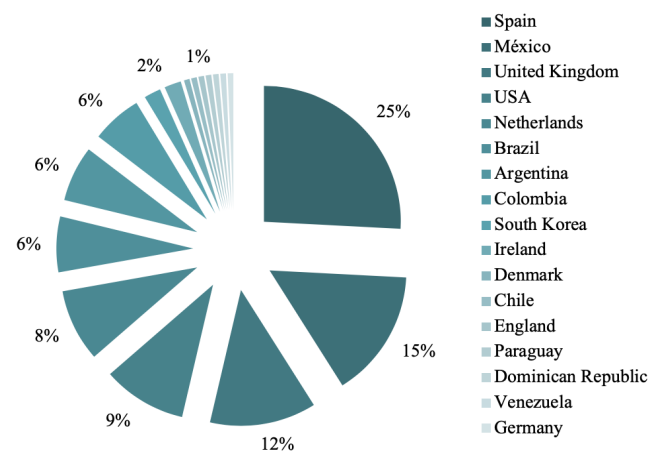

Fig. 2. Representativeness of publication countries according to databases 
The information provided in figure 2 corresponds to the percentage of journals registered in each listed country, where the topic technological competence figures as part of its publication scope. For the pie chart depicted in figure 2, considering $100 \%$ of all selected publications in the SRL. Countries are listed in decreasing order of its percent value, being Spain, Mexico, United Kingdom, USA and the Netherlands the countries with the highest percent value, having $25 \%, 15 \%, 12 \%, 9 \%$, and $8 \%$ respectively for each one. Brazil, Argentina and Colombia are represented with 6\%; and with minimum representation are South Korea and Ireland with $2 \%$, and Denmark, Chile, England, Paraguay, Dominican Republic, Venezuela and Germany with 1\% each.

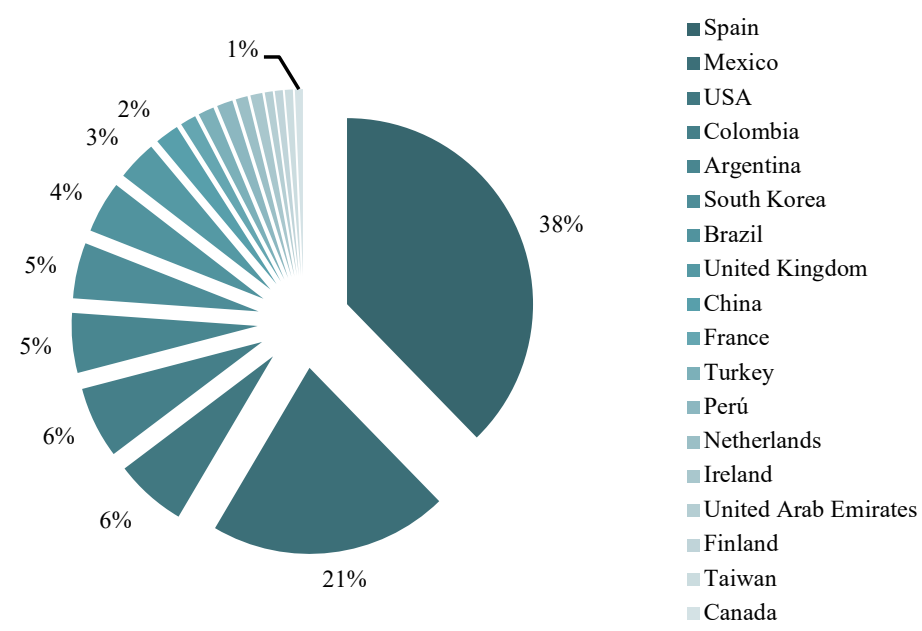

Fig. 3. Percentage of authors per country that have studied the term technological competence

The pie chart shown in figure 3 represents the percentage of research works per country conducted in higher education institutions or research centers that periodically publish studies related to the technological competences subject. Among the listed countries, Spain, México, USA and Colombia figure with $38 \%, 21 \%, 6 \%$, and $6 \%$, respectively. With moderate to low participation are Argentina, South Korea, Brazil, United Kingdom and China having 5\%, 5\%, 4\%, 3\% and 2\% each. Finally, with minimum participation are France, Turkey, Peru, Netherlands, Ireland, United Arab Emirates, Finland, Taiwan and Canada.

\subsection{Technological competence-conceptual analysis}

Transformation of the term throughout the time: The analysis of the term technological competence was carried out based on the comparison among the perspective of different authors and considering various approaches proposed within the field of application of the term. The papers selected to conduct the analysis were those that specifically studied the technological competence from a conceptual point of view, and, from them, it is determined if the concept has undergone any change over time. 
From the analysis, it was observed that most of changes identified in the concept of technological competence correspond to the addition of elements that diversify the definition of the term, although they do not modify the foundations of the basic structure. The scope of the study contemplates the analysis of papers published along a period of 22 years. The number of published papers per year is summarized in figure 4 together with a reference map.

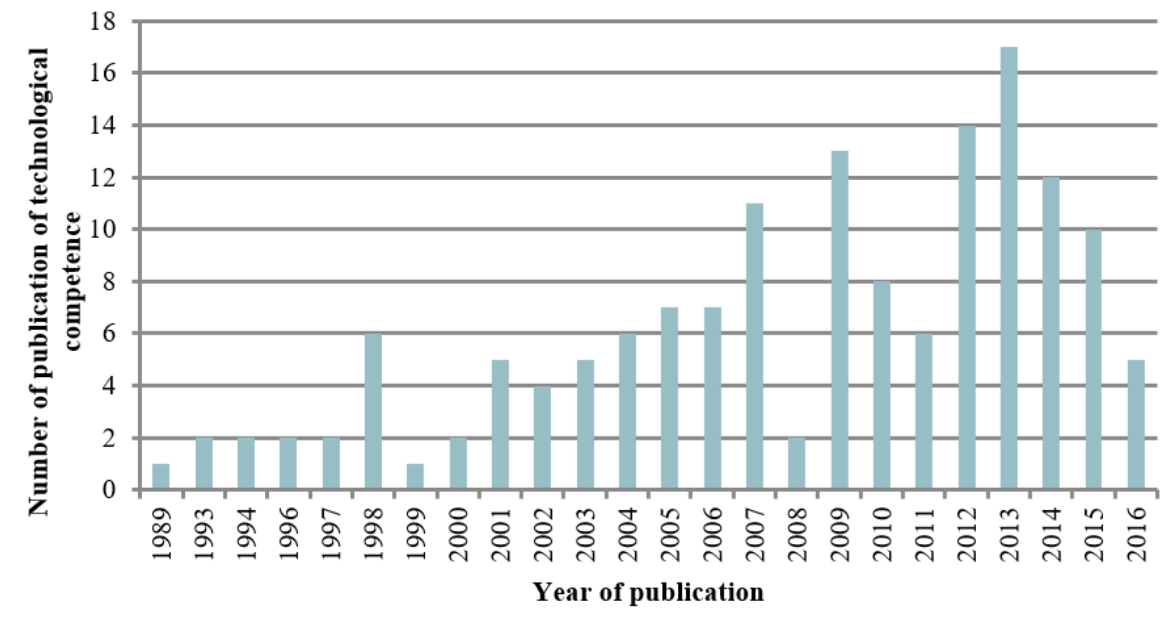

Fig. 4. Number of publications per year

Authors list: The procedure for data analysis is based on a researchers' triangulation approach. The approach is characterized by the comparison of several interdisciplinary contributions, proposed in multiple areas of knowledge.

The references selected for conducting the conceptual study of the technological competence are listed in table 3 . Here, the references are classified according to their nomenclature, focus, and cross-references. Cross-references are those references included in the reviewed papers, which contribute to the construction of the theoretical basis of the research work, and to the conceptual construction of the term. Furthermore, a diversity of nomenclatures for the technological competence term is described, and similar conception and application patters are found within the different approaches explored in each area of knowledge.

From the results is observed that $56 \%$ of the papers are related to an industrial (enterprise) approach, $37 \%$ to educational approach, and $2 \%$ to the economical one. Likewise, cross-references that include a specific definition for the technological competence are identified in their corresponding reference.

In the educational ambit, the concept of technological competence is oriented to the specialized teacher training. There is evidence of studies where universities are designing strategies for teachers training and for integrating technological elements within the classroom. Also, administrative processes designed as a response to the demands of a national development plan focused on innovation provide significant 
information regarding the concept of technological competence. In general, the key elements of such studies are teachers and students.

In the enterprise approach, the term technological competence is defined from a broader context. In this field, technology is particularly required by the urge for update along with the problems caused by the growing digital gap in industry, which is alarming. In [19] learning in industrial environments is addressed and the need for the development of technological competences is analyzed. The work is carried out within the electrical sector, but it can easily be extended to consider multiple productive fields. In [22] the results of the integration of three elements - vision, resources and capabilities - are presented. This integration is provided by the development of individual or collective learning processes. The learning processes incorporate different technological flows of the enterprise, envisioning the necessity of collaboration in order to embrace the technological development and the construction of new paradigms of innovation in an industry [20].

Marc Giget was a pioneer in the definition and representation of the term technological competence within the industry. Back in the 80's decade, Giget was analyzing the Japanese industry and its potentialities. He explained, in an original and symbolic way, the function of technology in industry by means of a tree structure [72] and by 1997, he conceptualized the term technological competence, which has been the benchmark for over 70 research works [21]. The definition provided by Giget in [21] integrates three main edges named as knowledges. The edges describe knowing how to conceive, how to produce and how to sell, and also includes the entire administrative cycle of an industry, not only the use of technology as an element external to the processes and activities of the industry. As a result of the analysis, it is stated that Marc Giget is the seminal author of the concept given its contribution to the administrative approach with the paper L'Innovation dans l'enterprise in 1996 [20].

Table 3.

\begin{tabular}{|c|c|c|c|}
\hline Ref & Nomenclature & Focus & Definition / Cross Ref \\
\hline$[18]$ & Technological competences & Educational & $\begin{array}{l}\text { "Knowing how to make use of new technologies, especially } \\
\text { informatics technologies, in two senses, as sources of information } \\
\text { and as tools for processing, ordering and analyzing data" }\end{array}$ \\
\hline [19] & Technological competences & Business & $\begin{array}{l}\text { "It is used to define a new strategic core of the company, through } \\
\text { a broad connotation that includes not only the proficiency of the } \\
\text { technologies themselves, but also all the elements of knowledge } \\
\text { accumulated by the company. In particular: Know how to con- } \\
\text { ceive, due to the technological proficiency and the ability to } \\
\text { identify markets. Know how to produce, due to the knowledge of } \\
\text { processes and costs, the ability to organize production, internally } \\
\text { or externally. Know how to sell, for the domination of distribution } \\
\text { networks and communication" [20][21] } \\
\text { "It is the result of the integration of three elements: vision, } \\
\text { resources and capabilities, which is eased by the development of } \\
\text { feedback processes of learning, individually or collectively } \\
\text { originated, that incorporate the different technological trends of } \\
\text { the company." [22] }\end{array}$ \\
\hline$[23]$ & Technological competences & Educational & $\begin{array}{l}\text { "Finite system of cognitive dispositions that allow us to do } \\
\text { infinite actions to successfully perform into an environment } \\
\text { mediated by artifacts and cultural tools" }\end{array}$ \\
\hline [24] & Technological competencies & Business & $\begin{array}{l}\text { "They are the technical assets of a company. Competences are a } \\
\text { subset of the capabilities in a company" }\end{array}$ \\
\hline
\end{tabular}




\begin{tabular}{|c|c|c|c|}
\hline$[25]$ & Technological competences & Business & $\begin{array}{l}\text { "Is the result of the integration of three elements defined and } \\
\text { controlled by the company: the strategic challenge, technological } \\
\text { resources and dynamic capabilities, which implies knowing how } \\
\text { to conceive, produce and sell." [20][26] }\end{array}$ \\
\hline [27] & Technological competence & Business & $\begin{array}{l}\text { "Organization and technical capacity involved in achieving a } \\
\text { certain level of production performance with technological } \\
\text { effects" [28] } \\
\text { "Collective learning in the organization, especially how to } \\
\text { coordinate the different production techniques and integrate } \\
\text { multiple technologies flows."[29] }\end{array}$ \\
\hline [30] & $\begin{array}{l}\text { Technological competence } \\
\text { ICT Competence }\end{array}$ & Business & $\begin{array}{l}\text { "Potentiate the curricular integration of information technolo- } \\
\text { gies"[31] }\end{array}$ \\
\hline [32] & $\begin{array}{l}\text { Technological distinctive } \\
\text { competencies }\end{array}$ & Business & $\begin{array}{l}\text { "Process of technological innovation, being a flow magnitude that } \\
\text { allows describing processes for the generation of technological } \\
\text { knowledge" [33] } \\
\text { "Unique combination of knowledge and capabilities that allow } \\
\text { generating a number of profitable innovations" [34][35] }\end{array}$ \\
\hline$[36]$ & \begin{tabular}{|l|} 
Technological competence \\
Technological specialization
\end{tabular} & Business & $\begin{array}{l}\text { "National technological competences determine the technological } \\
\text { specialization of a country" }\end{array}$ \\
\hline$[37]$ & $\begin{array}{l}\text { Technological competence } \\
\text { Technological capability }\end{array}$ & Economic & $\begin{array}{l}\text { "They are expressions of the knowledge assets of a company, } \\
\text { operating in different levels of the productive apparatus" [28][38] } \\
\text { "It considers having the knowledge and skills to understand, make } \\
\text { use and make decisions about technology" [39] }\end{array}$ \\
\hline$[40]$ & $\begin{array}{l}\text { Technology/Technological } \\
\text { Competences Technology } \\
\text { Management Competence }\end{array}$ & Business & $\begin{array}{l}\text { "Include basic technical skills that involve knowledge of tech- } \\
\text { niques designed to carry out business processes, and the use of } \\
\text { tools and equipment necessary to perform an operational activity" }\end{array}$ \\
\hline$[41]$ & $\begin{array}{l}\text { Computer competence } \\
\text { Technological competence } \\
\text { Digital competence }\end{array}$ & Educational & $\begin{array}{l}\text { Informatics competence } \\
\text { "Set of capabilities acquired in the informatics field that enable } \\
\text { the possibility to proficiently interact with the computer, in } \\
\text { addition to recognizing and identifying its elements, for personal, } \\
\text { academic and /or professional purposes, by using specific soft- } \\
\text { ware in order to manage information, communication and to solve } \\
\text { problems" [42] } \\
\text { "Set of knowledge, skills, dispositions and behaviors that train the } \\
\text { individuals to know how the ICT work, what they are used for, } \\
\text { and how they can be used to achieve specific objects." [43] } \\
\text { Technological competence } \\
\text { "Knowledge of the possibilities brought out from the new tech- } \\
\text { nologies for improving teaching. Making use of the ICT in } \\
\text { educational field, as for example, in the organization of the } \\
\text { teaching-learning processes that take place in the classroom. } \\
\text { Select, use, design and produce ICT-based teaching materials that } \\
\text { promote acquiring meaningful learning y that turn the classroom } \\
\text { into a lab where student's responsibility and prominence are } \\
\text { encouraged" [44] } \\
\text { Digital competence } \\
\text { "It involves the safe and critical use of Information Society } \\
\text { Technologies (IST) for work, leisure and communication. It is } \\
\text { based on the core competences of TSI: the use of computers to } \\
\text { obtain, evaluate, store, produce, present and exchange infor- } \\
\text { mation, communicate and participate in collaboration networks } \\
\text { through the Internet" [45] } \\
\text { Informative competences } \\
\text { "It is the set of knowledge, skills, dispositions and behaviors that } \\
\text { enable individuals to recognize when they need information, } \\
\text { where to find it, how to assess their suitability, and use it accord- } \\
\text { ingly to a given problem. It is common to all disciplines, to all } \\
\text { learning environments, to all levels of education. It allows ap- } \\
\text { prentices to master the content and expand their research, to be } \\
\text { more autonomous and take more control of their own learning" }\end{array}$ \\
\hline
\end{tabular}




\begin{tabular}{|c|c|c|c|}
\hline & & & $\begin{array}{l}\text { [43] } \\
\text { ICT competences or ICT use competences } \\
\text { "Use ICT as a tool for expression and communication, for provid- } \\
\text { ing access to sources of information, as a mean for documents and } \\
\text { data storage, for presentation tasks, research learning and collabo- } \\
\text { rative work" [46] }\end{array}$ \\
\hline$[47]$ & $\begin{array}{l}\text { Technological/Electronics } \\
\text { competence } \\
\text { e-Competence/e-skills/IT- } \\
\text { skills }\end{array}$ & Business & $\begin{array}{l}\text { "The knowledge, skills, abilities and attitudes of taking advantage } \\
\text { of the new information technologies, used for education or for } \\
\text { work, and, in general, for any process of knowledge generation. It } \\
\text { involves the ability to apply specific knowledge and use the } \\
\text { know-how to solve cognitive and practical problems" }\end{array}$ \\
\hline$[48]$ & Technological competence & Business & $\begin{array}{l}\text { "Finite system of cognitive dispositions that allow us to do } \\
\text { infinite actions to successfully perform into an environment } \\
\text { mediated by artifacts and cultural tools" [23] }\end{array}$ \\
\hline [49] & $\begin{array}{l}\text { Technological distinctive } \\
\text { competencies }\end{array}$ & Business & $\begin{array}{l}\text { "They are identified by the current state and progress of science } \\
\text { and relevant technologies, also by generating advanced techno- } \\
\text { logical processes, assimilating new technologies and useful } \\
\text { innovations, attracting and retaining qualified scientific-technical } \\
\text { personnel, and mastering, generating or absorbing basic and } \\
\text { fundamental commercial technologies." } \\
\text { "The experience of the organization in the mobilization of diverse } \\
\text { scientific and technical resources, through a series of routines and } \\
\text { procedures that allow new products and production processes to } \\
\text { be developed and designed." [50][51] }\end{array}$ \\
\hline$[52]$ & Technological competence & Business & $\begin{array}{l}\text { "Resources needed to generate and manage improvements in } \\
\text { investments, processes and organization of production, products } \\
\text { and equipment. These resources are accumulated and incorpo- } \\
\text { rated into individuals (experience, skills and tacit knowledge) and } \\
\text { organizational systems." [53] }\end{array}$ \\
\hline$[54]$ & $\begin{array}{l}\text { Technological distinctive } \\
\text { competencies }\end{array}$ & Business & $\begin{array}{l}\text { "It refers to the capability for obtaining information about the } \\
\text { status and progress of science and technology. Capability to } \\
\text { generate advanced technological processes, to assimilate new } \\
\text { technologies and useful innovations, to attract and retain their } \\
\text { qualified technical-scientific personnel, to master, generate or } \\
\text { absorb technology. Efficiency in the creation of programs aimed } \\
\text { to the development of competences or the absorption of technolo- } \\
\text { gy, either from TR\&D centers, or suppliers and customers" } \\
\text { (definition obtained from the description of the evaluation instru- } \\
\text { ment) }\end{array}$ \\
\hline$[55]$ & $\begin{array}{l}\text { Technological competence } \\
\text { /digital/ICT }\end{array}$ & Business & $\begin{array}{l}\text { "Capability, knowledge and attitude about the use of ICT over its } \\
\text { various functions and application contexts" }\end{array}$ \\
\hline$[56]$ & $\begin{array}{l}\text { Technological competence } \\
\text { Technological specialization }\end{array}$ & Business & $\begin{array}{l}\text { "It represents the regularity of the technological activity of a } \\
\text { country in the different technical or knowledge fields, this is, the } \\
\text { technical areas in which the country develops technological } \\
\text { entrepreneurships, among all the technological possibilities" [57] }\end{array}$ \\
\hline$[58]$ & Technological competence & Business & $\begin{array}{l}\text { "The ability to identify, accumulate, codify and apply different } \\
\text { types of knowledge. It determines, to an important extent, the } \\
\text { capacity of a company to undertake processes of learning, both } \\
\text { internal and external. The more advanced the competences, the } \\
\text { greater the capacity to codify the tacit knowledge that circulates } \\
\text { within the company and to absorb external knowledge." }\end{array}$ \\
\hline$[59]$ & Digital competence & Economic & $\begin{array}{l}\text { "The ability to search, obtain and process information, as well as } \\
\text { to use it in a critical and systematic way, evaluating its relevance } \\
\text { and identifying the differences and links between real and virtual } \\
\text { information. People must be able to use tools to produce, present } \\
\text { and understand complex information, and have the necessary } \\
\text { skills to access, search for and use Internet-based services, but } \\
\text { they must also know how to use information society technologies } \\
\text { to support the critical thinking, creativity and innovation" [45] }\end{array}$ \\
\hline$[60]$ & $\begin{array}{l}\text { Digital competence } \\
\text { ICT Competence } \\
\text { Computer competence }\end{array}$ & Educational & $\begin{array}{l}\text { "The necessity to acquire knowledge, skills and attitudes that } \\
\text { enable people to interact with ICT as the acquisition of other } \\
\text { skills such as teamwork, learning to learn, etc., is facilitated. } \\
\text { Technology not only stimulates creativity and innovation, but also } \\
\text { contributes to intercultural dialogue and plays an important role to } \\
\text { overcome individual learning problems." [42][43][45][61][62] }\end{array}$ \\
\hline
\end{tabular}




\begin{tabular}{|c|c|c|c|}
\hline$[63]$ & $\begin{array}{l}\text { Technological competence } \\
\text { Digital competence } \\
\text { e-skills }\end{array}$ & Business & $\begin{array}{l}\text { "Concept that includes different types of dynamic competences } \\
\text { and levels, particularly in those jobs that require highly special- } \\
\text { ized technical knowledge. It is increasingly necessary that any } \\
\text { employee has some degree of digital competences that allows him } \\
\text { to perform his work exploiting ICT." }\end{array}$ \\
\hline$[64]$ & ICT competence & Educational & $\begin{array}{l}\text { "Those referred to the knowledge and use of different telematics } \\
\text { tools" [65] }\end{array}$ \\
\hline$[66]$ & $\begin{array}{l}\text { e-Competence/ICT skill/e- } \\
\text { skill/digital skills/ICT } \\
\text { Professional }\end{array}$ & Business & $\begin{array}{l}\text { "Skills needed by citizens to face their social, personal and } \\
\text { professional life. The ICT skills of the end users are at the level of } \\
\text { digital literacy and are required by all those who live in the } \\
\text { information society." }\end{array}$ \\
\hline$[67]$ & Digital competence & Educational & $\begin{array}{l}\text { "Secure, critical and creative use of ICT to achieves the objectives } \\
\text { related to work, employability, learning, leisure, inclusion and/or } \\
\text { society participation" [68] } \\
\text { "Combination of knowledge, abilities and attitudes related to the } \\
\text { ICT, developed by people in real situations, in order to effectively } \\
\text { and efficiently achieve specific goals." [69] }\end{array}$ \\
\hline$[70]$ & Technological competence & Business & $\begin{array}{l}\text { "Organization's ability to efficiently manage its technological } \\
\text { processes, in such a way that it can competitively develop its } \\
\text { production processes" [71] }\end{array}$ \\
\hline
\end{tabular}

Theoretical basis of the former definition of the technological competence term are the studies related to the core competences [11][12][13][14][15][16][17][26][29][34] within the management field of knowledge, where the capabilities and skills necessary to train industry leaders are defined, in order to increase their competitiveness and move up in their careers. Core competences are generally considered as activities or techniques for technical incorporation in addition to multiple action lines. That is the main reason why authors that usually study this term, end up being part of the theoretical timeline of the technological competence term, even though they do not literally belong to the construction of the concept. The concept of technological competence represents a whole set of elements taken from the core competences area.

Nomenclatures given to the term technological competence: The data obtained from the analysis related to the description and classification of the term technological competence according the nomenclature assigned to it is summarized in figure 5. From these results, it can be observed that $51 \%$ of the works employed the name technological competence, which represents the majority of the analyzed papers. The second place goes to the name digital competence which is observed in $14 \%$ of the papers, followed by ICT competence - where ICT stands for Information and Communication Technologies - with $8 \%$, and at last are computer competence and technology management, with $6 \%$ and $3 \%$, respectively. It is worth mentioning that this nomenclature list corresponds only to the specific names used by authors, but the definitions managed for each name present similar features. 


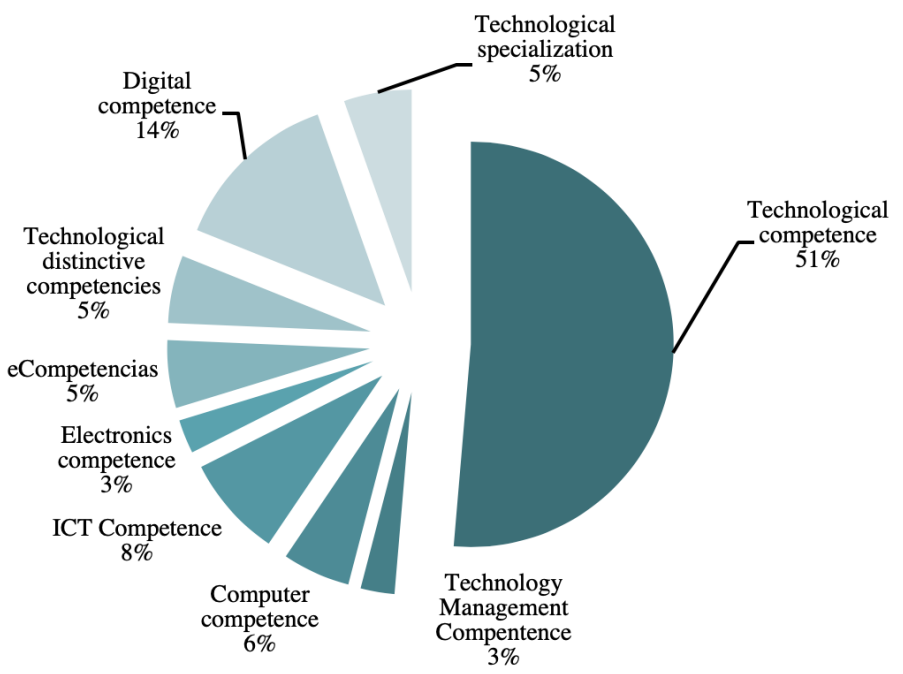

Fig. 5. Use of the term of technological competence

Application approaches associated to the terms - conceptual relationship diagram: It is interesting to dive into the research proposal of each author and how are they related. This is, it is necessary to analyze and classify the authors that include a reference framework in the resulting papers of their studies. In figure 6, the relationship among authors, with respect to their citations, is presented. The diagram is organized by blocks according to the approach, or to the area of knowledge. The citation from an author to another is marked by a line, with the arrow indicating the direction of the relationship - from the author who cites to the cited author -. Also, the nomenclature assigned by each author to the term and the year of publication are indicated.

In the relationship diagram can be clearly observed the evolution of the term technological competence along each of the approaches. From this relationship is possible to state the following results:

- The authors Barroso \& Morales [52] manifest an intersection between the technological competence and technological capability terms. Therefore, they are recognized as the authors that formally connects both terms within the boundaries of the definition.

- Several authors that conduct research about core competences [26][28][29][33][34], which represent a broader level of professional competences, remark the importance of technological skills. In [22][25] Morcillo establishes a conceptual relationship between the works of the seminal author [20] and [19], as well as the relationship with the core competence concept, as provided in [26][29]. 


\subsection{Conceptual comparative with respect to the technological competences}

Concepts like technological competence, capability, or skill, are historically used without distinction in the literature. However, it is necessary to precise the terms in order to clarify the approaches and their political, administrative, training and strategic implications.

Technological capability: The concept of technological capability has been studied during the history of the development of industry. The term is pointed out and adapted by multiple authors inside the industrial approach. Some of the related works can be found in [53][73][74][75][76][77][78][79][80][81][82][83][84][85][86][87] [88][89][90][91][92][93][94][95][96][97][98][99]. The aforementioned publications try to reconsider the trends of the worldwide productive sector by integrating ICCT to daily activities, by conducting descriptive analysis inside the companies, and by promoting new progress trends.

The relationship between the technological competence and capability is carried out based on the analysis of the verbs, actions and elements names as representative features of each concept.

Table 4 presents a list of the specific elements identified repetitively and relevant to the description of the technological competence and technological capability terms. It is also observed that some representative features are common to both terms, but the term technological competence adds some specific features, which are remarked in the table. The definition of the technological competence concept implies a more extensive description, with more actions, as compared to the technological capability.

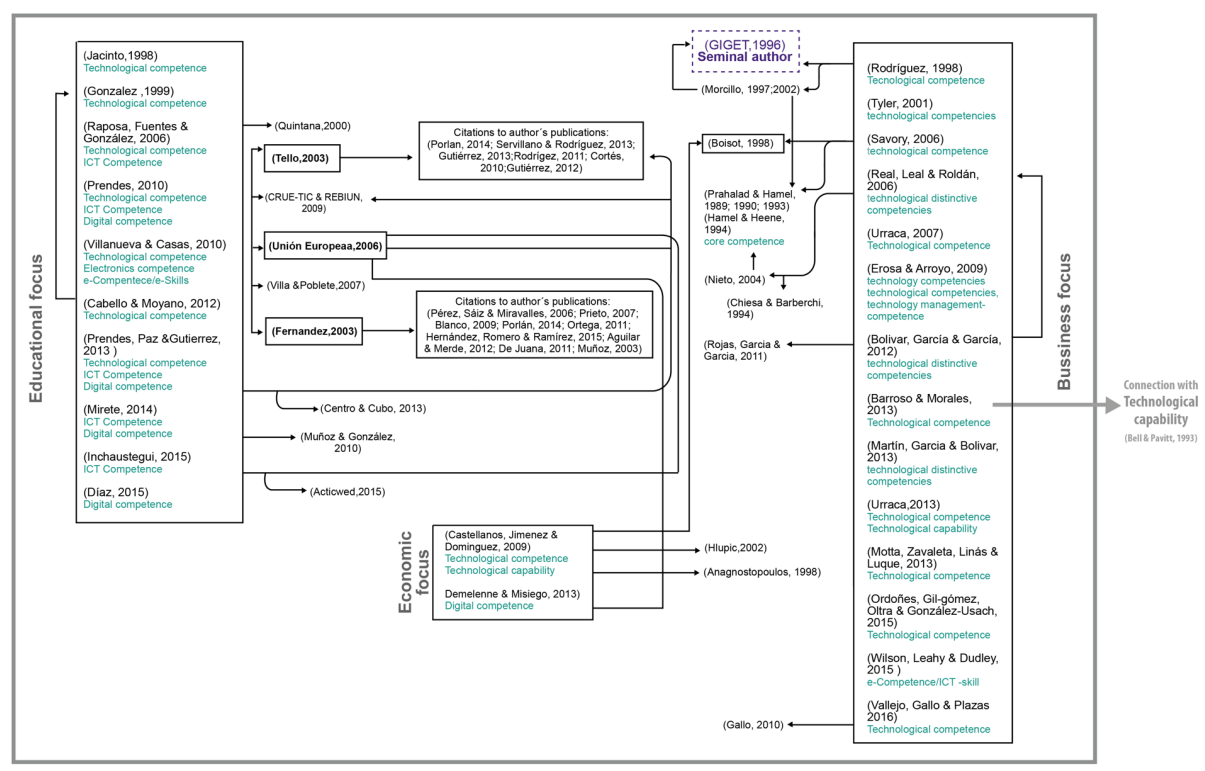

Fig. 6. Authors of publications and their research relationships 
Table 4. Conceptual differences between competence and technological capacity

\begin{tabular}{|l|l|}
\hline \multicolumn{1}{|c|}{ Term } & \multicolumn{1}{|c|}{ Representative feature of the concept } \\
\hline Technological competence & Expertise, aptitude, suitability \\
& Know how to conceive, technological domain, market capacity \\
& Vision, resources, capabilities \\
& Strategic challenge, technological resources, dynamic capabilities \\
& Knowledge and skills (understand, make use, decision making) \\
& Knowledge-skill-ability-attitude \\
& To solve cognitive and practical problems \\
\hline Technological capability & Generate resources, manage resources \\
& Organization, production and equipment \\
& Skill, efficient use \\
& Use, adopt, change, create new technology \\
& Appropriating, transferring, developing (technology) \\
\hline
\end{tabular}

Technological skill: The term technological skill, within the area of interest, is defined and treated as a resource or tool associated to characteristics of human capital, described as an important foundation of the technological competences acquired by a company's personnel. The concept of technological skill is further analyzed from an administrative, economic or marketing point of view. Therefore, it is applied to the industry evolution and personnel development [100][101][102][103][104][105] [106][107] [108][109][110][111][112].

The relationship between technological competences and e-skills is easier to break down because the role of each term in the study context is delimited by the etymology of the concepts. In [101], the positioning of the e-skills inside of an organization is studied. In this work, besides describing the importance of the e-skills, the boundaries existing with the concept of e-competence, defined by the European e-Commerce Framework [113], are stated. In [113], the technological competences and skills for the industry in Europe are described. They state that the set of skills form a competence, and backwards, the set of competences define a profile or level of knowledge.

\section{Discussion and Conclusion}

\subsection{Elements that characterize the technological competence term}

The technological competences are characterized by the technological domain. This is represented by the coincidences identified in the definitions assigned by the reviewed authors.

From an enterprise approach, it implies the capacity of identifying markets, producing new products or services, efficient data management, skills to manage the technical assets of the company, as well as the capability to face strategical and dynamic challenges in the current globalization trends [19][20][21][22][23][24][25][26] [27][28][29][32][33][35][36][40][49][51][52][54][56][58][63][66][70][71][72].

From an economical approach, it is identified that the decisions made based on technology and the use of critical thinking for innovation, represent important features for the concept [39][59]. 
From an educational approach, the speech diverges, and the definition is oriented to the use of technological artifacts and services, the relationship with computers and software, the improvement of teaching, meaningful learning provided from technological mediation, and to the generation of learning control $[18][23][30][41][42][43][44][45][46][47][48][60][62][64][65][67][69]$.

Two relevant features for the definition of technological competence are identified in [40][65], cited mainly as conduct dispositions that train the individuals [58][60], cognitive problems solving [64], and in second plane, the consideration of the context of learning and the interculturality, which represent important variables for the analysis of the term [72][77].

There are two determinant elements of the technological competence definition that evolve along with the concept and differentiate it from other term. In the former, it is referred to the mastery of distribution, communication and collaboration networks, collective work and learning, and the statement of team work $[20][21][22][29][45][46]$. In the latter, the development of qualified personnel, technological absorption for generating technological development and innovation centers, the development of technological entrepreneurship centers, and the establishment of processes for start new companies [54][56][58][114].

Another group of authors write about the technological competence term within the framework of action proposals. This is, the term is addressed from government sources, or private training institutions, putting aside the conceptual approach. They are focused on the analysis of indicators and considerations for establishing models oriented to the development of technological competences. With international coverage, are the studies proposed in [115][116][117][118][119][120][121][122][123][124] $[125][126][127][128][128][130][131][132][133][134][135][136]$. In the national extent, the works [137][138] are considered. Meanwhile, in the regional coverage, where the region is regarded as the Mexican's north border state of Baja California, the studies of [139] and [140] are identified. The last 26 mentioned studies differentiate from the rest of the rest of the references of this work because of the application approach. While the first data mainly consider conceptual and theoretical values, the final data is focused on proposals for technology incursion, which point out the direction of the term and the future work.

\subsection{Approaches of the technological competence term}

As stated in the section 4.1, the technological competence concept is located within three main approaches, represented by the area of knowledge in which the concept is studied:

- Industrial approach, representing the research oriented to case studies in industry and productive sector, with the administrative sciences, marketing and enterprise development concepts involved

- Educational approach, the studies are carried out in a psychological education level, directed to the development of teaching-learning strategies, where most of research is pointed to improve the level of technological knowledge in teachers 
- Economical approach, it apparently can be linked to the industrial approach, but it is a novel research trend distinguished by the fact that technology is considered as an exclusively financial growth strategy for organizations.

Giget is identified as the seminal author for contributing the technological competence term in 1996, which was applied to the industry. Giget has been cited by numerous authors, starting in 1997 to the most recent works. He envisions a changing environment inside companies achieved through training and continuous improvement of its personnel, while an economical approach is also considered [20].

Authors build the term based on core theoretical considerations. The selected approach for the technological competence term is defined by citations and by previous reviews made by theoretical researchers from the administrative, economic and educational areas. In general, tight collaboration between industry and economical approaches is expected. In the industry approach, only the trend related to the work area is envisioned. Meanwhile, for the educational approach, authors analyze the term strictly limited by its profile, and they hardly make references to the proposals made in different areas.

\subsection{Terms associated to the technological competences.}

The term technological competence is directly linked to the meanings technological capability and technological skill. Therefore, it is straightforward to identify the necessity of analyzing those concepts and the intersection of their definitions. Each term is individually analyzed and thereafter the relationship existing among the terms is collectively reviewed. Moreover, the key features that serve as links among the terms are identified.

Figure 7 provides a graphical representation of the terms' relationship. It is pointed out that the technological competence is a result from the development of specific technical skills and innovation. Therefore, technological skills figure as the theoretical basis for the technological competences. Also, it would not be possible to develop technological competences without the capability for applying the knowledge provided by them. In this case, technological capability is referred as the necessary resources for generating and managing improvements for products, services and processes, including human capital. Technological capability resources are gradually incorporated to individuals by continuous learning, this is, they can be accumulated.

For the purpose of this investigation, the correlation's middle point is set for the terms. In order to determine this middle point, the definitions made in [23][45][69] are considered, and the technological concept for industry is reframed.

The evaluation of technological competences can be based on the term's correlation, given that the principles for generating measurement instruments, markers and metrics are identified for each plane. 


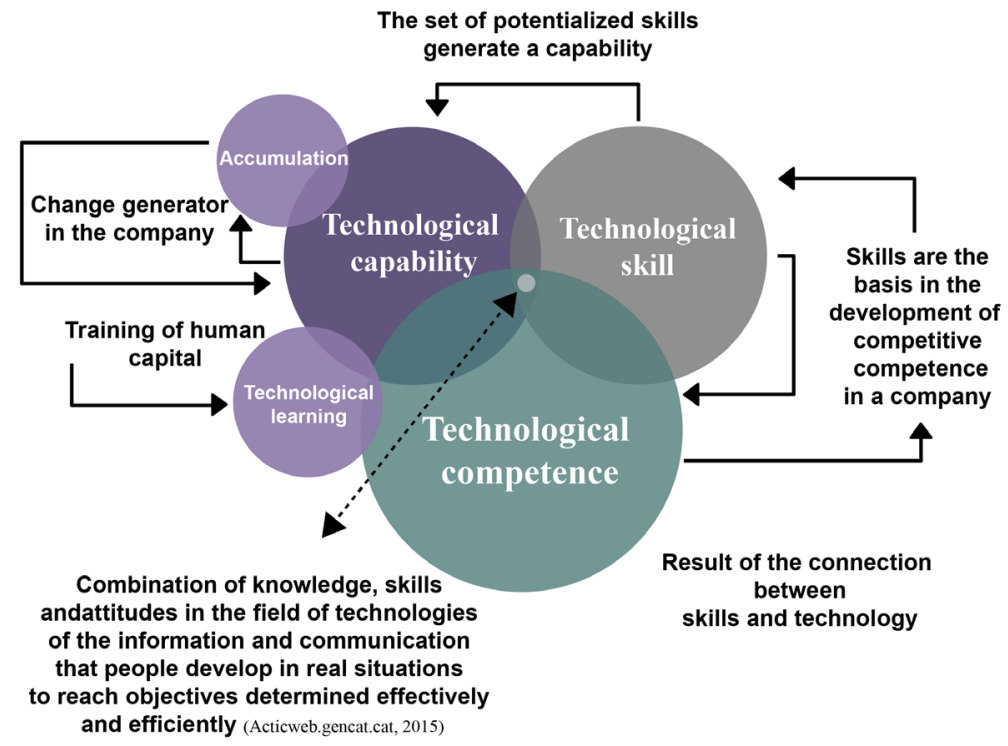

Fig. 7. Conceptual correlation between competence, capacity and technological skill

\subsection{Reconsideration of the technological competence term related to the industry}

From the SRL and data analysis, a definition for the term technological competence is constructed, convenient for its application to the productive sector. The conceptualization of the technological competence is drawn from an integral and systematic vision, and considers a corporative and industrial perspective:

Set of cognitive, attitudinal and value dispositions that allows developing human capital inside of an organization, to interact and master the conscious or unconscious use of Information, Communication and Collaboration Technologies, as referred to the technological appropriation and incubation for innovation in services, processes or products that provide benefits and business growth, strictly based on the collaborative work of the personnel.

This conceptual construction is structured with the objective of defining the term technological competence oriented to the organizational analysis, centered on human capital, aiming to the corporate development, both social and economic, visualizing technological expertise from a "conscious" state, but more important, considering the "unconscious" state, because it represents the ideal state in which individuals do not perceive ICT incorporation as an instrumental element, but as a transparent, day-today and spontaneous relationship with technology. It is relevant to assume collaborative work as a main feature because learning and skills development is generated by the organization's collective experience, personal experiences and the context. 


\subsection{Future work}

The rationale for conducting a conceptual analysis of the technological competences and related terms is the future necessity for constructing a technological competence profile that considers all the criteria derived from a broad concept oriented to the industry. It is necessary to weight and describe evaluation criteria in order to identify the level of technological competence of human capital in the productive sector. This would be impossible without the background provided by the theoretical information assigned to the term, concepts relationship, identification of authors that study the term and the analysis of the main international, national and regional application projects.

\section{$5 \quad$ References}

[1] Hitt, M. A., Ireland, R. D., \& Lee, H. U. (2000). Technological learning, knowledge management, firm growth and performance: an introductory essay. Journal of Engineering and Technology management, 17(3-4), 231-246. https://doi.org/10.1016/S09234748(00)00024$\underline{2}$

[2] Lee, J. J., \& Yoon, H. (2015). A comparative study of technological learning and organizational capability development in complex products systems: Distinctive paths of three latecomers in military aircraft industry. Research Policy, 44(7), 1296-1313. https://doi.org/10 .1016/j.respol.2015.03.007

[3] Bawden, D. (2002). Revisión de los conceptos de alfabetización informacional y alfabetización digital. In Anales de documentación (Vol. 5, pp. 361-408).

[4] García Morales, V. J. (2005). Analisis de las barreras del aprendizaje organizacional desde la perspectiva de los centros educativo. Revista de dirección, organización y administración de empresas, 31, 46-63.

[5] Garcia-Morales, V. J., Llorens-Montes, F. J., \& Verdú-Jover, A. J. (2006). Antecedents and consequences of organizational innovation and organizational learning in entrepreneurship. Industrial Management \& Data Systems, 106(1), 21-42. https://doi.org/10.1108/ $\underline{02635570610642940}$

[6] Cardona, D. M., \& Sánchez, J. M. (2010). Indicadores Básicos para Evaluar el Proceso de Aprendizaje en Estudiantes de Educación a Distancia en Ambiente e-learning. Formación universitaria, 3(6), 15-32. https://doi.org/10.4067/S0718-50062010000600004

[7] Morales, V. J. G., Martínez, M. M. R., \& Montes, F. J. L. (2007). Liderazgo transformacional: influencia en la visión compartida, aprendizaje, innovación y resultado organizativo. Revista Europea de Dirección y Economía de la empresa, 16(4), 24-46.

[8] Morales, V. J. G., Barrionuevo, M. J., \& Montes, F. J. L. (2011). Influencia del nivel de aprendizaje en la innovación y desempeño organizativo: factores impulsores del aprendizaje/Influence of the Level of Learning in the Organizational Innovation and Performance: Driving Factors of Learning. European Journal of Management and Business Economics, 20(1), 161.

[9] Kocoglu, I., Imamoglu, S. Z., Ince, H., \& Keskin, H. (2012). Learning, R\&D and manufacturing capabilities as determinants of technological learning: enhancing innovation and firm performance. Procedia-social and behavioral sciences, 58, 842-852. https://doi.org/10.1016/j.sbspro.2012.09.1062

[10] Husain, Z., Dayan, M., \& Di Benedetto, C. A. (2016). The impact of networking on competitiveness via organizational learning, employee innovativeness, and innovation process: 
A mediation model. Journal of Engineering and Technology Management, 40, 15-28. https://doi.org/10.1016/i.jengtecman.2016.03.001

[11] Hamel, G., \& Prahalad, C. K. (1996). Compitiendo por el futuro. Editorial Ariel.

[12] Torkkeli, M., \& Tuominen, M. (2002). The contribution of technology selection to core competencies. International journal of production economics, 77(3), 271-284. https://doi. org/10.1016/S0925-5273(01)00227-4

[13] Sánchez, A. V., \& Ruiz, M. P. (2011). Evaluación de competencias genéricas: principios, oportunidades y limitaciones. Bordón. Revista de pedagogía, 63(1), 147-170.

[14] Palma, M., de los Ríos, I., \& Miñán, E. (2011). Generic competences in engineering field: a comparative study between Latin America and European Union. Procedia-Social and Behavioral Sciences, 15, 576-585. https://doi.org/10.1016/j.sbspro.2011.03.144

[15] Martín-Rojas, R., García-Morales, V. J., \& Bolívar-Ramos, M. T. (2013). Influence of technological support, skills and competencies, and learning on corporate entrepreneurship in European technology firms. Technovation, 33(12), 417-430. https://doi.org/10.1016/j. technovation.2013.08.002

[16] Zhang, M. J., \& Lado, A. A. (2001). Information systems and competitive advantage: a competency-based view. Technovation, 21(3), 147-156. https://doi.org/10.1016/S0166$\underline{4972(00) 00030-4}$

[17] Lampel, J. (2001). The core competencies of effective project execution: The challenge of diversity. International Journal of Project Management, 19(8), 471-483. https://doi.org/10. $1016 / \mathrm{S} 0263-7863(01) 00042-4$

[18] Jacinto, C. (1998). Competencias laborales y formación profesional de jóvenes. Seminario Juventud y formación para el trabajo. San Pablo: CEIL-CONICET Fundación W.K. Kellogg.

[19] Rodríguez, P. J. (1998). La tecnología y el aprendizaje organizativo como base de la ventaja competitiva: una aplicación de la matriz estratégica de competencias tecnológicas en el sector eléctrico Español. Madrid, España: Universidad Autónoma de Madrid. Facultad de Ciencias Económicas y Empresariales. Departamento de Contabilidad y Organización de Empresas.

[20] Giget, M. (1996). L'Innovation dans l'entreprise. Techniques del l'Ingenieur.

[21] Giget, M. (1997). Technology, innovation and strategy: recent developments. Internacional Journal of Technology Management, 14, 613-634. https://doi.org/10.1504/IJTM.1997. $\underline{002583}$

[22] Morcillo, P. (1997). Dirección estratégica de la tecnología e innovación. Madrid.

[23] González, J. A. (1999). Tecnología y percepción social evaluar la competencia tecnológica. Estudios sobre las culturas contemporáneas, V (9), 155-165.

[24] Tyler, B. B. (2001). The complementarity of cooperative and technological competencies: a resource-based perspective. Journal Engineering and Technology Manegement Jet-M, 18, 1-27. https://doi.org/10.1016/S0923-4748(00)00031-X

[25] Morcillo, P. (2002). La integración de las competencias tecnológicas y personales como fuente de ventajas competitivas para la empresa. Revista Tribuna de Debate, 9.

[26] Prahalad, C., \& Hamel, G. (1994). Competing for the future. Harvard Business School.

[27] Savory, C. (2006). Translating knowledge to build technological competence. Emerald, 44 (8), 1052-1075. https://doi.org/10.1108/00251740610690612

[28] Boisot, M. (1998). Knowledge assets: Securing Competitive Advantage Information Economy. Oxford University Press.

[29] Prahalad, C., \& Hamel, G. (1990). The core competences of the corporation (Vol. 68). Harvard Business Review. 
[30] Raposo, M., Fuentes, E., \& González, M. (2006). Desarrollo de competencias tecnológicas en la formación inicial de maestros. Revista latinoamericana de tecnología educativa , 5 (2), 525-537.

[31] Quintana, J. (2000). Competencias en tecnologías dela información del profesorado de educación infantil y primaria. Revista Interuniversitaria de Tecnología Educativa.

[32] Real, J. C., Leal, A., \& Roldán, J. L. (2006). Information technology as a determinant of organizational learning and technological distinctive competencies. Industrial Marketing Management, 505-521. https://doi.org/10.1016/j.indmarman.2005.05.004

[33] Nieto, M. (2004). Basic propositions for the study of the technological innovation process in the firm (Vol. 7). European Journal of Innovation Management. https://doi.org/10. $1108 / 14601060410565065$

[34] Hamel, G., \& Heene, A. (1994). Competence-Based Competition. USA: Universidad de California.

[35] Chiesa, V., \& Barbeschi, M. (1994). Technology strategy in competence-based competition. Competence-based competition, 293, 314.

[36] Urraca, R. A. (2007). Patrones de inserción de las empresas multinacionales en la formación de competencias tecnológicas de países seguidores. Revista Brasileira de Innovación, 405432

[37] Castellanos, D. O., Jiménez, H. C., \& Domínguez, M. K. (2009). Technological competence: a conceptual basis for technological development in Colombia. Revista Ingeniería e Investigación, 29 (1), 133-139.

[38] Hlupic, V. (2002). Knowledge and Business Process Management. (I. G. (IGI), Ed.) ilustrada.

[39] Anagnostopoulos, C. N. (1998). Few gold stars for precollege education. IEEE Spectrum, 18-26. https://doi.org/10.1109/6.666954

[40] Erosa, V. E., \& Arroyo, P. E. (2009). Technology Management Competences Supporting the Business Strategy. (M. I. Universidad Autónoma de Tamaulipas, Ed.) México, Tamaulipas: PICMET 2009 Proceedings. https://doi.org/10.1109/PICMET.2009.5261911

[41] Prendes, E. M. (2010). Competencias TIC para la docencia en la Universidad pública Española: Indicadores y propuestas para la definición de buenas prácticas. Informe del proyecto EA2009-0133 de la Secretaría de Estado de Universidades e Investigación. Universidad de Murcia, Grupo de Investigación tecnología educativa.

[42] Tello, D. J. (2003). Competencia informática del profesorado de Infantil y Primaria en Huelva y su incidencia en la práctica docente. Huelva, Andalucía: Universidad de Huelva.

[43] CRUE-TIC \& REBIUN. (2009). Competencias informáticas e informacionales en los estudios de grado. España.

[44] Fernández, M. R. (2003). Competencias profesionales del docente en la sociedad del siglo XXI. Revista Fórum Europeo de Administradores de la Educación, 11 (1).

[45] Unión Europea. (2006). Programme eLearning. Recovered: 2 de mayo del 2016 de: http://eur-lex.europa.eu/

[46] Villa, A., \& Poblete, M. (2007). Aprendizaje basado en competencias. Una propuesta para la evaluación de las competencias genéricas. (E. mensajero, Ed.) Bilbao: Universidad de Deusto.

[47] Villanueva, G., \& Casas, M. d. (2010). e-Competencias: nuevas habilidades del estudiantes en la era de la educación, la globalidad y la generación de conocimiento. Signo y pensamiento, XXIX, 124-138

[48] Cabello, R., \& Moyano, R. (2012). Tecnologías interactivas en la educación. Competencias tecnológicas y capacitación para la apropiación de las tecnologías. Buenos Aires, Argentina: Universidad Nacional de General Sarmiento. 
[49] Bolívar, R. M., García, M. V., \& García, S. E. (2012). Technological distinctive competencies and organizational learning: Effects on organizational innovation to improve firm performance. Journal of Engineering and Technology Management, 331-357. https://doi.org/10.1016/i.jengtecman.2012.03.006

[50] Real, J. C., Leal, A., \& Roldán, J. L. (2006). Information technology as a determinant of organizational learning and technological distinctive competencies. Industrial Marketing Management, 505-521. https://doi.org/10.1016/j.indmarman.2005.05.004

[51] Rojas, M., García, M. V., \& García, S. E. (2011). The influence on corporate entrepreneurship of technological variables. Industrial Management \& Data System, 111 (7), 984-1005. https://doi.org/10.1108/02635571111161253

[52] Barroso, R. S., \& Morales, Z. D. (2012). Trayectoria de acumulación de competencias tecnológicas y procesos de aprendizaje. Propuesta de un modelo analítico para agencia de viajes y operadoras turísticas. Estudios y perspectivas en turismo, 21, 515-532.

[53] Bell, M., \& Pavitt, K. (1993). Technological accumulation and industrial growth: contrasts between developed and developing countries. Industrial and corporate change, 2 (2), 157 211. https://doi.org/10.1093/icc/2.2.157

[54] Martín, R. R., García, M. V., \& Bolívar, R. M. (2013). Influence of technological support, skills and competencies, and learning on corporate entrepreneurship in Europa technology firms. Technovation, 417-430. https://doi.org/10.1016/j.technovation.2013.08.002

[55] Prendes, E., Paz, M., \& Gutiérrez, P. I. (2013). Spanish University Teachers Technological Competencies. Revista de Educación, 196-222.

[56] Urraca, R. A. (2013). Especialización tecnológica, captura y formación de competencias bajo integración de mercados; comparación entre Asia y América Latina. Economía y Sociedades, 22 (3), 641-673.

[57] Patel, P., \& Pavitt, K. (1997). The technological competencies of the world's largest firms: complex and path-dependent, but not much variety. Research policy, 26(2), 141-156. https://doi.org/10.1016/S0048-7333(97)00005-X

[58] Motta, J. J., Zavaleta, L., Llinás, I., \& Luque, L. (2013). Innovation processes and competences of human resources in the software industry of Argentina. Revista CTS, 24, 147175.

[59] Demelenne, D., \& Misiego, P. (2013). La XO y los cambios en las prácticas docentes y en las interacciones en el aula en Paraguay. Desarrollo, Participación y Ciudadanía. Instituto de desarrollo. Paraguay: Centro Internacional de Investigaciones para el Desarrollo (IDRC), Canadá.

[60] Mirete, R. A. (2014). TIC y enfoques de enseñanza y aprendizaje en Educación Superior. Murcia: Facultad de Psicología. Universidad de Murcia.

[61] ITE. (2011). Competencia Digital. Instituto de Tecnologías Educativas. Departamento de Proyectos Europeos.

[62] Centeno, G., \& Cubo, S. (2013). Evaluación de la competencia digital y las actitudes hacia las TIC del alumnado universitario. Revista de Investigación Educativa, 31 (2), 517-536. https://doi.org/10.6018/rie.31.2.169271

[63] Ordoñez, J. E., Gil-Gómez, H., Oltra, B. R., \& González-Usach, R. (2015). Importancia de las competencias en tecnologías de la información (e-skills) en sectores productivos. Propuesta de investigación en el sector transporte de la comunidad Valenciana. 3Ciencias TIC, 4 (12), 87-99.

[64] Inchaustegui, S. A. (2015). Percepción de las Competencias TIC del profesorado Universitario Dominicano. Caso UNAPEC. España: Universidad de Murcia. 
[65] Muñoz, C. P., \& González, S. M. (2010). Análisis del grado de formación del profesorado de la universidad de A Coruña en el área de programación y bases de datos bajo sistemas de e-learning. Pixed-Bit. Universidad de Sevilla, 36, 101-114.

[66] Wilson, D., Leahy, D., \& Dudley, D. (2015). The European e-competence framework: Past, Present and Future. IADIS International Journal on Computer Science and Information Systems, 10 (1), 1-13.

[67] Díaz, G. M. (2015). Competencias respecto a las TIC de los estudiantes universitarios del ámbito de Educación. Valencia, España: Universitat de València-Estudi General Facultat de Filosofia i Ciències de l'Educació Departament de Mètodes d'Investigació i Diagnòstic en Educació.

[68] Comisión Europea. (2006). Propuesta de recomendación del parlamento Europeo y del Consejo relativa a la creación del Marco Europeo de Cualificaciones para el aprendizaje permanente.

[69] AcTIC. (2015). ACTIC. Generalitat de Catalunya. Recovered: 18 de 05 de 2017 de: http://web.gencat.cat/ca/inici/

[70] Vallejo, B. M., Gallo, J. J., \& Plazas, C. E. (2016). Propuesta de una metodología para el estudio de competencia tecnológica en empresas fabricantes de medicamentos. Universidad \& Empresa, 18 (31), 11-27. https://doi.org/10.12804/rev.univ.empresa.31.2016.01

[71] Gallo, J. (2010). Estudio de la relación proveedor-productor en la gestión de materiales del sector farmacéutico industrial productivo (SFIP) de la ciudad de Bogotá, Colombia. Colombia: Universidad Nacional de Colombia.

[72] Giget, M. (1984). The Bonsai tree of Japanese industry. FUTURES.

[73] Lall, S. (1992). Technological capabilities and industrialization. World development, 20 (2), 165-186. https://doi.org/10.1016/0305-750X(92)90097-F

[74] Kim, L. (1997). From imitation to innovation. The Dynamics of Korea's Technological Learning.

[75] Kim, L. (1997). The dynamics of Samsung's technological learning in semiconductors. California Management Review, 39 (3), 86-100. https://doi.org/10.2307/41165900

[76] Kim, L. (1999). Learning and innovation in economic development. Cheltenham, UK: Edward Elgar Publishing Limited.

[77] Dutrénit, G. (2000). Learning and knowledge management in the firm: from knowledge accumulation to strategic capability. Edward Elgar.

[78] Dutrénit, G. (2004). Building technological capabilities in latecomer firms: a review essay. Science Technology Society, 9, 209-241. https://doi.org/10.1177/097172180400900202

[79] [62] Figueiredo, P. (2001). Technological learning and competitive performance. Edward Elgar.

[80] Figueiredo, P. (2002). Does technological learning pay off? Inter-firm differences in technological capability-accumulation paths and operational performance improvement. Research Policy, 31, 73-94. https://doi.org/10.1016/S0048-7333(01)00106-8

[81] Figueiredo, P. (2009). Gestão da inovação: conceitos, métricas e experiências de empresas no Brasil". LTC.

[82] Lam, A. (2005). Organizational innovation. The Oxford Handbook of Innovation.

[83] Ariffin, N., \& Bell, M. (1999). Firms, politics and political economy: patterns of subsidiary-parent linkages and technological capability-building in electronics TNC subsidiaries in Malaysia. In: Jomo, K.S.; Rasiah,R;Felker,G , 150-186.

[84] Ariffin, N., \& Figueiredo, P. (2004). Internalisation of innovative capabilities: counterevidence from the electronics industry in Malaysia and Brazil. Oxford development studies, 32, 559-583. https://doi.org/10.1080/1360081042000293344 
[85] Bell, M. (1984). Learning and the accumulation of industrial technological capacity in developing countries. King,K \& Fransman M, 187-202.

[86] Bell, M., \& Guiliani, E. (2007). Catching up in the global wine industry: innovation systems, cluster knowledge networks and firm-level capabilities in Italy and Chile. International Journal of Technology and Globalisation, 3, 197-223. https://doi.org/10.1504/ IJTG.2007.014333

[87] Lee, J., Lee, Y., Lim, G. G., \& Yoo, W. S. (2007, November). Exploring information technology competence of a firm. InConvergence Information Technology, 2007. International Conference on (pp. 1263-1268). IEEE.

[88] Dutrénit, G., Lee, K., Nelson, R., Soete, L., \& Vera-Cruz, A. (Eds.). (2013). Learning, capability building and innovation for development. Springer. https://doi.org/10.1057/ 9781137306937

[89] Sampedro Hernández, J. L. (2013). Innovación y cambio microinstitucional en el sector salud: evidencia de la telemedicina en México. Economía: teoría y práctica, (39), 31-57.

[90] Figueiredo, P. N. (2005). Acumulação tecnológica e inovação industrial: conceitos, mensuração e evidências no Brasil. São Paulo em perspectiva, 19(1), 54-69. https://doi.org/10.1590/S0102-88392005000100005

[91] Dutrénit, G., \& Vera-Cruz, A. O. (2005). Technological capability accumulation in the'maquila industry'in Mexico. Cadernos EBAPE. BR, 3(SPE), 01-16. https://doi.org/10. 1590/S1679-39512005000500016

[92] Dutrénit, G., \& Arias, A. (2003). Acumulación de Capacidades Tecnológicas locales de empresas globales en México: El caso del centro técnico de Delphi Corp. CTS+ I: Revista Iberoamericana de Ciencia, Tecnología, Sociedad e Innovación, (6), 3.

[93] Navarro, A. A. (2004). Acumulación de Capacidades Tecnológicas: El caso de la empresa curtidora Alfa. Investigación económica, 101-123.

[94] Ortega Rangel, R. (2005). Aprendizaje y acumulación de capacidades tecnológicas en un grupo del sector siderúrgico. Innovar, 15(25), 90-102.

[95] Laredo, J. B., Garambullo, A. I., Martínez, V. V. F., \& Zepeda, A. S. O. (2016). Desempeño productivo y creación de capacidades tecnológicas en empresas multinacionales en México: estudio de casos múltiples. Global de negocios, 4(6), 95-103.

[96] Figueiredo, P. N. (2003). Learning, capability accumulation and firms differences: evidence from latecomer steel. Industrial and corporate change, 12(3), 607-643. https://doi.org/10.1093/icc/12.3.607

[97] Figueiredo, P. N., Gomes, S., \& Farias, R. (2010). Innovative technological capability in firms of the tourism sector: a study of the hotels in the city of Rio de Janeiro during the 1990-2008 period. Revista de Administração Pública, 44(5), 1139-1170. https://doi.org/10.1590/S0034-76122010000500007

[98] Dutrénit, G., Vera-Cruz, A. O., \& Navarro, A. A. (2003). Diferencias en el perfil de acumulación de capacidades tecnológicas en tres empresas mexicanas. El trimestre económico, 109-165.

[99] Wang, Y., Lo, H. P., \& Yang, Y. (2004). The constituents of core competencies and firm performance: evidence from high-technology firms in China. Journal of Engineering and Technology Management, 21(4), 249-280. https://doi.org/10.1016/j.jengtecman.2004. $\underline{09.001}$

[100] Várallyaia, L., \& Herdon, M. (2013). Reduce the Digital Gap by Increasing E-Skills. Procedia Technology Elsevier, 340 - 348. https://doi.org/10.1016/j.protcy.2013.11.045

[101] Mitrovic, Z. (2010). Positioning e-skills within an organisation: an information systems management viewPoint. SA Journal of Information Management, 12 (1), 7. https://doi.org/ $\underline{10.4102 / \text { sajim.v12i1.427 }}$ 
[102] Hawking, P., \& Stein, A. (2002). E-skills: The Next hurdle for ERP implementations. IEEE Computer Society

[103] European Commission. (2012). e-SKILLS AND ICT PROFESSIONALISM. Fostering the ICT Profession in Europe.

[104] European Commission. (2014). e-SKILLS: THE INTERNATIONAL DIMENSION AND THE IMPACT OF GLOBALISATION. European Commission DG Enterprise and Industry.

[105] European Commission. (2014). e-Skills for Jobs in Europe Measuring Progress and Moving Ahead

[106] Baralou, E. (2010). IT Skills: The Business Gain Measuring Employees' Efficiency after e-skills training \& certification. ALBA Graduate Business School.

[107] Youssef, A. B., \& Dahmani, M. (2013). Information technologies, students' e-skills and diversity of learning process. Springer Science+Business Media.

[108] Cobo, J. C. (2009). Strategies to Promote the Development of E-competencies in the Next Generation of Professionals: European and International Trends. SKOPE Publications.

[109] Kirsch, M. (2010). Evaluation of the European e-skills week. EDU.Consult.

[110] Evans, N. (2002). Chapter 2 Information Technology Jobs and Skill Standards. In B. Hawkins, J. Rudy, \& W. Wallace, Technology Everywhere A Campus Agenda for Educating and Managing Workers in the Digital Age (pp. 25-38). EDUCAUSE.

[111] UKCES. (2012). Information and Communication Technologies: Sector Skills Assessment 2012. UK Commission for Employment and Skills.

[112] UKCES. (2013). Technology and skills in the Construction Industry. UK Commission for Employment and Skills.

[113] European e-Commerce Framework. (2000). E-Commerce directive. European eCommerce. Recovered: https://ec.europa.eu/digital-single-market/en/e-commerce-directive

[114] Brito, J., Garambullo, A., \& Ferreiro, V. (2014). Aprendizaje y Acumulación de Capacidades Tecnológicas en la Industria Electrónica en Tijuana. Revista Global de Negocios, 2 (2), 57.

[115] Cascales Martínez, A., Martínez Segura, M. J., \& Gomariz Vicente, M. Á. (2016). Competencia tecnológica y trabajo colaborativo en las prácticas curriculares del Grado en Pedagogía en la Universidad de Murcia. Revista de Investigación en Educación, 14(1), 31-52.

[116] Lee, H., Park, J., \& Lee, J. (2013). Role of leadership competencies and team social capital in IT services. Journal of Computer Information Systems, 53(4), 1-11. https://doi.org/10. 1080/08874417.2013.11645645

[117] Martín-Rojas, R., García-Morales, V. J., \& Mihi-Ramírez, A. (2011). How can we increase Spanish technology firms' performance? Journal of Knowledge Management, 15(5), 759778. https://doi.org/10.1108/13673271111174311

[118] Miñán, E., Lavalle, C., \& Díaz-Puente, J. M. (2012). Relevance Evaluation of Engineering Master's Program in Peru. Procedia-Social and Behavioral Sciences, 46, 1557-1564. https://doi.org/10.1016/j.sbspro.2012.05.340

[119] García-Morales, V. J., Bolívar-Ramos, M. T., \& Martín-Rojas, R. (2014). Technological variables and absorptive capacity's influence on performance through corporate entrepreneurship. Journal of Business Research, 67(7), 1468-1477. https://doi.org/10.1016/j. jbusres.2013.07.019

[120] Tyler, B. B. (2001). The complementarity of cooperative and technological competencies: a resource-based perspective. Journal of Engineering and technology management, 18(1), 1-27. https://doi.org/10.1016/S0923-4748(00)00031-X 
[121] Díaz-Díaz, N. L., Aguiar-Díaz, I., \& De Saá-Pérez, P. (2008). The effect of technological knowledge assets on performance: The innovative choice in Spanish firms. Research Policy, 37(9), 1515-1529. https://doi.org/10.1016/j.respol.2008.06.002

[122] Fernandez-Perez, V., Jesus Garcia-Morales, V., \& Fernando Bustinza-Sanchez, O. (2012). The effects of CEOs' social networks on organizational performance through knowledge and strategic flexibility. Personnel Review, 41(6), 777-812. https://doi.org/10.1108/ 00483481211263719

[123] De Jong, J. P., \& Marsili, O. (2006). The fruit flies of innovations: A taxonomy of innovative small firms. Research policy, 35(2), 213-229. https://doi.org/10.1016/j.respol. $\underline{2005.09 .007}$

[124] Zheng, M., \& Bao, G. (2005). The impact of a company's technology strategy on its technology competence, technology acquisition and firm performance in Chinese SMEs. In Engineering Management. IEEE International (Vol. 1, pp. 175-179).

[125] García Sánchez, E., Martín Rojas, R., \& Fernández Pérez, V. (2016). ¿ Los activos tecnológicos fomentan la capacidad de absorción? Contabilidad y Negocios, 11(22).

[126] Cabello, R., \& Moyano, R. (2006). TIC y EDUCACIÓN: Competencias Tecnológicas y capacitación para la apropiación de las tecnologías. Razón y palabra, (49), 139.

[127] Cabello, R. (2011). Migraciones digitales como propuesta de alfabetización mediática digital en la formación docente. Enseñar con tecnologías. Nuevas miradas en la formación docente. Buenos Aires: Prometeo.

[128] Hamel, G. (1993). The future for strategy: An interview with Gary Hamel. European Management Journal, 11(2), 150-157. https://doi.org/10.1016/0263-2373(93)90038-J

[129] Hamel, G., \& Prahalad, C. K. (1996). Competing in the new economy: Managing out of bounds. Strategic management journal, 237-242. https://doi.org/10.1002/(SICI)10970266(199603)17:3<237::AID-SMJ829>3.0.CO;2-G

[130] Morcillo, P. (2012). Siempre nos quedará la innovación. Revista europea de dirección y economía de la empresa, 21(3), 215-218. https://doi.org/10.1016/j.redee.2012.05.002

[131] Bueno, E., Morcillo, P., \& Anton, J. M. R. (1997). Management of technology: Proposal for a diagnosis model. The Journal of High Technology Management Research, 8(1), 6387. https://doi.org/10.1016/S1047-8310(97)90014-6

[132] Rodríguez Pomeda, J., Morcillo Ortega, P., Fernández de Navarrete, F., \& Rodríguez Antón, J. (2001). Technological competencies and competitive advantage in the Spanish Electricity Industry: New challenges, new tools. International Journal of Innovation Management, 5(04), 457-485. https://doi.org/10.1142/S1363919601000452

[133] McLaughlin, S., Sherry, M., Carcary, M., \& O'Brien, C. (2012). e-SKILLS AND ICT Professionalism. Fostering the ICT Profession in Europe. Final Report 2012.

[134] Gareis, K., Hüsing, T., Birov, S., Bludova, I., Schulz, C., \& Korte, W. (2014). E-skills for jobs in Europe: Measuring progress and moving ahead. Prepared for European Commission.

[135] Kolding, M., \& Kroa, V. (2007). E-skills: The key to employment and inclusion in europe. IDC White Paper, Sponsored by Microsoft.

[136] McLaughlin, S., Sherry, M., Doherty, E., Carcary, M., Thornley, C., Wang, Y., ... \& Heusing, T. (2014). e-Skills: The International dimension and the Impact of Globalisation-Final Report 2014.

[137] Vokes, C., \& Brennan, J. (2013). Technology and skills in the construction industry.

[138] García Alcaraz, J. L., \& Romero González, J. (2011). Valoración subjetiva de los atributos que los ingenieros consideran requerir para ocupar puestos administrativos: Un estudio en empresas maquiladoras de Ciudad Juárez. Revista mexicana de investigación educativa, 16(48), 195-219. 
[139] Fuentes, N. (2005). Elementos de la politica de desarrollo empresarial: El caso de Baja California, México. Comercio exterior, 55(5), 441-449.

[140] Ahumada-Tello, E., Zarate Cornejo, R. E., Plascencia López, I., \& Perusquia Velasco, J. M. A. (2012). Modelo de Competitividad Basado en el Conocimiento: El Caso de las Pymes del Sector de Tecnologías de Información en Baja California (Productivity Model Based on Knowledge-The Case of the Information Technology Pymes in Baja California).

\section{Authors}

Norma Candolfi Arballo, student of the doctorate in Educational Systems and Environment of the University of Guadalajara (Mexico), master's degree in Engineering from the Autonomous University of Baja California (Mexico), currently a fulltime professor at the School of Engineering and Technology Sciences (UABC). Leader of the Academic group for Continuing Education Research at a Distance. It belongs to the Quality Network of Education Mediated by the TICC and the Network of Education Supported in Information Technologies, Communication and Collaboration. Member of the Mexican Network of Researchers in Emerging Technologies in Education.

María Elena Chan Núñez is a full-time research professor at the University of Guadalajara and a member of the National System of Researchers. With a specialization in Distance Education by the UNAM and Paris 2, a Master's Degree in Communication from the ITESO in Guadalajara and a Doctorate in Education from the University of Guadalajara. She is currently Head of the Institute of Knowledge Management and Learning in Virtual Environments IGCAAV of the Virtual University System of the University of Guadalajara.

Bernabé Rodríguez Tapia, PhD student in Technology from the Autonomous University of Ciudad Juárez (Mexico), master's degree in Engineering from the Autonomous University of Baja California (Mexico), currently a full-time professor at the School of Engineering and Technology Sciences (UABC). Member of the Academic group of Investigation of Continuing Education at a Distance. It belongs to the Network of Quality of Education Mediated by the TICC and to the Network of Supported Education in Information Technology, Communication and Collaboration.

Article submitted 28 June 2018. Resubmitted 21 November 2018. Final acceptance 05 December 2018. Final version published as submitted by the authors. 